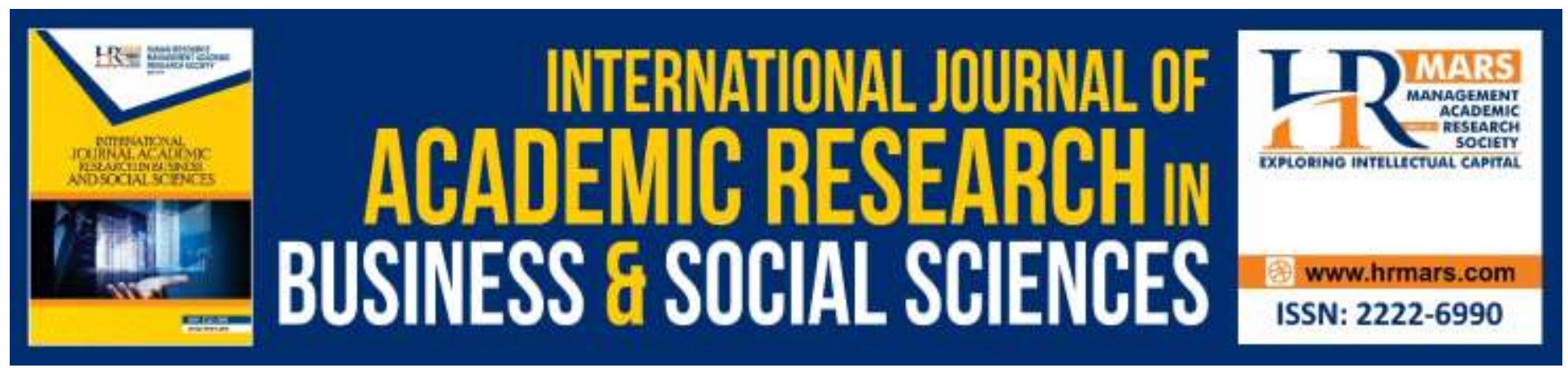

\title{
Truth-Claim Shift: Philosophical Studies on Former Terrorism Inmate in Indonesia
}

\author{
Waston Waston, Aminudin Hassan
}

To Link this Article: http://dx.doi.org/10.6007/IJARBSS/v9-i10/6494

DOI: 10.6007/IJARBSS/v9-i10/6494

Received: 17 Aug 2019, Revised: 20 Sept 2019, Accepted: 10 Oct 2019

Published Online: 30 Oct 2019

In-Text Citation: (Waston \& Hassan, 2019)

To Cite this Article: Waston, W., \& Hassan, A. (2019). Truth-Claim Shift: Philosophical Studies on Former Terrorism Inmate in Indonesia. International Journal of Academic Research in Business and Social Sciences, 9(10), 315-335.

Copyright: (C) 2019 The Author(s)

Published by Human Resource Management Academic Research Society (www.hrmars.com)

This article is published under the Creative Commons Attribution (CC BY 4.0) license. Anyone may reproduce, distribute, translate and create derivative works of this article (for both commercial and non-commercial purposes), subject to full attribution to the original publication and authors. The full terms of this license may be seen

at: http://creativecommons.org/licences/by/4.0/legalcode

Vol. 9, No. 10, 2019, Pg. 315 - 335

http://hrmars.com/index.php/pages/detail/IJARBSS

JOURNAL HOMEPAGE

Full Terms \& Conditions of access and use can be found at http://hrmars.com/index.php/pages/detail/publication-ethics 


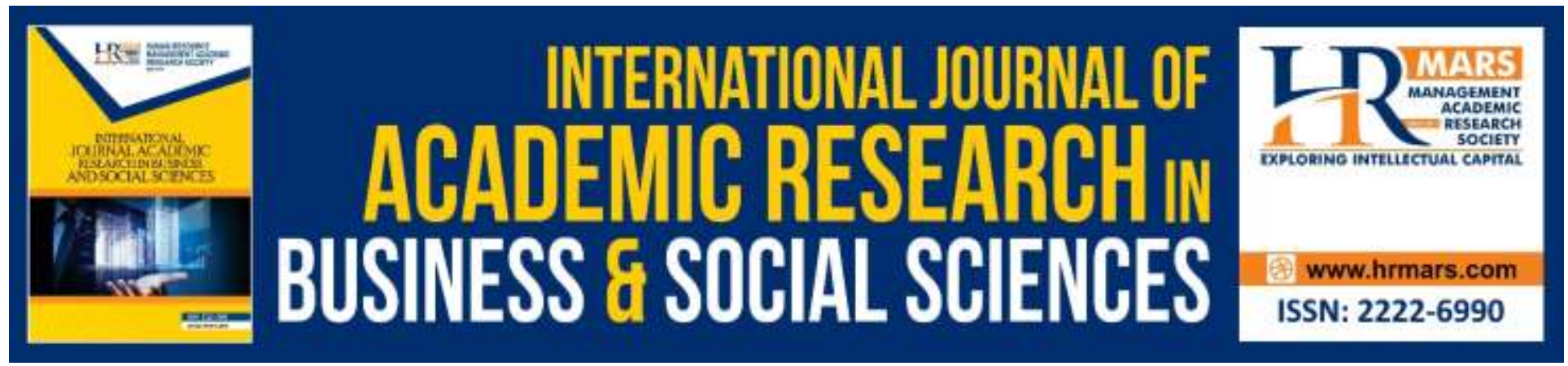

\title{
Truth-Claim Shift: Philosophical Studies on Former Terrorism Inmate in Indonesia
}

\author{
Waston Waston \\ Islamic Education Doctoral Program, Universitas Muhammadiyah Surakarta, Indonesia \\ Aminudin Hassan \\ Faculty of Educational Studies, Universiti Putra Malaysia
}

\begin{abstract}
This study explores a gradual shift of thought on truth claim hold by former terrorist inmates (known in Indonesia as ex-napiter). It is based on data interviews with three ex-napiter, namely, Yusuf, a former jihadist in Southeast Asia who was accused of storing explosives and planning a bombing at Sri Rejeki brothel in Semarang; Wawan, who was charged due to his involvement in Bali Bombing 2 and hiding terrorist kingpin; and Mamo, a former member of Negara Islam Indonesia (Indonesian Islamic State) and an expert on assembling firearms. The study shows that the ex-napiter gradually changed their perspective on truth claim in four stages. First is the conflict period, where they cannot accept other truths except their own. Second is the independent period, which occurs when they have been caught by the police but have not yet accepted another truth. Third is the process of change, which produces dialogue about truths and raises the possibility of accepting other truths. Forth is the integration stage, where exnapiter have discovered new truths and be able to hold their own belief without necessarily rejecting the truth hold by the state. This study is expected to shed some lights on the perspectives of terrorist prisoners and former prisoners in Indonesia.
\end{abstract}

Keywords: Truth-Claim, Shift, Terrorism, Ex-Napiter, Islam, Indonesia

\section{Introduction}

Truth-claim often becomes the main reason for terrorists in carrying out their actions. Terrorists may stop their terror activities after a change of mind. Truth Claim Shift in this study is understood as a change of view of truth that shifted from the conflict to the integration paradigm. This shift sorts ex-napiter (ex-narapidana terorisme, former terrorism inmate) change from radical to moderate, from being hostile to the state of being pro-active to the government. This change is quite common among ex-napiter in Indonesia. The research focused on those who have so far been successful. 
The National Agency for Combating Terrorism (Badan Nasional Penanggulangan Terorisme, BNPT) notes that there are 271 terrorists in 68 Indonesian prisons. Some of them are already free and re-embrace to society who commonly known as ex-napiter. According to Suhardi Alius (the chief of BNPT), ex-napiter can be grouped into 4 (four) levels: core, militant, supporters, and sympathizers. For this first level the current core terrorists are 45 people. This group is noncooperative to government. To mention some of them are Maman Abdurrahman and Abu Bakar Baasyir. As for the second level or in the militant category there are 55 people, and it is now successfully approached by the government. Then the third level is 86 people. They tend to be cooperative to the government. Next is the level of sympathizer that currently rests 34 people. Those at this level are now working together and willing to follow the government programs. They discuss with the government to help reducing terrorism. They are often involved as speakers, both at national and international events. According to Suhardi Alius, there are about 70 more ex-terrorists who are now the speakers in the deradicalization program (Viva Media Baru, 2017).

The government deliberately involves ex-terrorists in the deradicalization movement. In Indonesia there have been many terrorists who eventually repent and become more moderate. Abdurahman Ayub, a former pupil of Abu Bakar Baasyir and Abdullah Sungkar has repented and left the terrorist group Jemaah Islamiyah (JI). Although the decision made his life threatened for being traitor, he declared to move to moderate Islam, and surrender to Allah for his life.(Fathurahman, n.d.) There is also Khairul Ghazali, a terrorism convict arrested by Densus 88 for involvement in a Bank CIMB Niaga robbery in Medan City that killed one of the members of Brimob, as well as involving an attack on the Hamparan Perak Police office. Khairul has regretted for his extreme understanding on jihad. He wants to change, even though it makes him threatened by his fellow jihadists(KompasTV, n.d.).

Another example of repentance and truth claim shift of terrorism prisoners is expressed by Iqbal Husaini, an alumni of Abu Sayyaf military training in the Philippines. He became a convicted terrorism because he saved and control firearms, ammunition and explosives for acts of terrorism in Indonesia. The man known as Ramli a.k.a Rambo finally repented after interacting with the civilians who were victims of the Bali Bombing.(Movanita, n.d.)

Another famous terrorist who has repented or experienced a truth claim shift is Umar Patek; a good example of former terrorist leader repentance. He was asked to hoist the Red and White flag in the ceremony of Hari Kebangkitan Nasional (National Resurgence Day) 2015 in Penitentiary Class 1 Porong, Sidoarjo, East Java. Umar Patek or Hisham bin Alizein changed after the long process of reflection and the kind treatment he received during in jail.

The repentance of terrorists proves that the terrorists have probability for change as long as they get the right treatment. The change from terrorist to moderate Muslim is a huge change. This truth-claim shift can occur because of various factors, both internal and external factors. From few examples of the repentance of terrorist convicts, it is known that each terrorist has different stages in achieving a change of religious outlook. Some are obtained gradually over the long term in part by short emotional events. Therefore, it is important to conduct research on the truth-claim shifting of former terrorist prisoners in a philosophical perspective. This 
philosophical study is expected to reveal in depth, holistic, and comprehensive about the change of mindset and truth claim of former convicted terrorists.

Considering the circumstances, the paper aims to: 1) Elaborate the concept of truth that the terrorists believe before experiencing a truth claim shift, 2) to reveal the factors that may cause a truth claim shift, 3) to understand the process of shifting truth claims of former terrorist prisoners, and 4) to explore the new views of former terrorism prisoners after experiencing a truth claim shift.

The study of terrorism in a philosophical perspective has indeed been done quite a lot. Nevertheless, as far as I concerned, the study of the shifting truth claims of ex-terrorism prisoners, from radical-terrorists to moderate- humanists, is almost never. To trace the originality and uniqueness of this study, the following I provide various studies or previous researches.

A.M. Hendropriyono in his dissertation entitled "Terorisme dalam Filsafat Analitika; Relevansinya dengan Ketahanan Nasional (Terrorism in Analytical Philosophy: Relevance to National Resilience)" states that terrorism is a social phenomenon that is difficult to understand, even by the terrorists themselves. Without adequate education, one can engage in acts of terrorism that thrill the world and have enormous implications. According to him, terrorist tactics and techniques continue to grow along with the advancement of science and technology, while the strategy develops along with ontological beliefs over ideology or philosophy that became his motive. Terrorism uses its own ways, expressions and language in the struggle to realize its goals. Furthermore, A.M. Hendropriyono explains that terrorists use their own epistemological justification and interpret the ideologies and expressions of truth by means of manipulating meaning. From a three-year study, A.M. Hendropriyono focused more on terrorism examined from the philosophy of language analytics, that is, the language of terrorism has family resemblance, as an analogy in one form of the same language game. The language used in terrorism turns out to be split over the two rules of language play, which are threatening and praying that are used at once. Hendro mentioned, the rules of language game that split in terrorism shows that terrorists have split personality. Terrorism actors also experience category turmoil, namely the inability to distinguish knowledge so that the subject and object of terrorism becomes infinite. Related to the relevance of the study of terrorism with national resilience, Hendro emphasizes the efforts to raise awareness of the need for revitalization of Pancasila philosophy, which covers the basic values, values of instruments, and values of praxis. Especially in the praxis level, it is necessary to prepare each program that is accommodative to various problems of society (Kesimpulan, 2009).

Muhammad Nursalim in his article entitled Deradikalisasi Terorisme: Studi Atas Epistemologi, Model Interpretasi dan Manipulasi Pelaku Teror (Deradicalisation of Terrorism: Studies of Epistemology, Interpretation Models and Manipulation of Terrorists) reveals that terrorism as an act of violence for the purpose of coercion of wills, coercion and expose that cost innocent civilian victims, very closely with politics. In a philosophical perspective, the root of violence arises in the phenomenon of human self-identification into; "Me and you" and much more into "us and them". This identification is the root of a violent hostility. Therefore, it is necessary to deradicalize terrorism through epistemology and interpretation model (Nursalim, 2014). 
Muhammad Kamal in his paper entitled "The Meaning of Terrorism: A Philosophical Inquiry" tried to investigate philosophically the meaning of terrorism. Kamal applies the Hegelian paradigm of "fight for recognition" as a basis for seeing the nature of the conflict between terrorists and others without connecting the conflict with certain phenomenological situations and cultures. Kamal makes clear boundaries between two types of conflicts, namely "fight for recognition and fight for annihilation. In the concept of fight for recognition, the existence of other people is still considered important so that there is no intention to annihilate others. Thus, the relationship between winners and losers only the problem is who becomes the master and who becomes the slave. But terrorists have different characteristics, they want annihilation. For them, perfect freedom will only occur if the others have vanished (Kamal, 2008).

Fatkhul Mufid in his article entitled "Islamic Radicalism in Epistemology Perspective" states that the extremism of fundamentalism is internally caused by several factors, such as the tendency to understand nash (text) literally, excessive attention to the problem of furu'iyah, lack of insight into the nature of Islam, and the weak discourse of historical scholarship in social life. The radicalism of Islam with its variants, in the struggle for Islamic Shari'a, the enforcement of the Islamic Caliphate, and various other agendas, all boils down to one point, that is to return to the Qur'an and As-Sunnah. The Qur'an and As-Sunnah are the only sources of doctrine, the source of knowledge, and the source of the law, and the only solution to solving the problems of the people. The methods used in understanding religion prefer the text literally and scripturally by denying all forms of contextual interpretation because it is feared to reduce absolutism and the universality of religious truth. According to them, the validity of the truth lies in the sacred text understood literally, as it is. Therefore, they reject the interpretation of religious texts with historical and sociological approaches that are considered to have brought people further away from the literal doctrine of scripture. In this context, they have a principle that society must adapt its development to the text of the scriptures, not the other way around (Mufid, 2016). The above studies have indeed discussed the theme of terrorism and radicalism in the perspective of philosophy, but researchers have not found a work that examines the shift truth-claims (ex-truth claims) of former inmates in a philosophical perspective. Thus, presumably this research can be regarded as an original study which is certainly different from the writings or previous studies.

\section{Theoretical Framework}

This study described how a person transitions from one truth position to another. Two positions in which the person is living are equally true, but in the "intermediate phase" there is falsification, where the new truth dismisses the old truth.

Truth is the correspondence between a statement (proposition) and reality. According to Kattsoff, philosophers of Idealism are among the most assertive supporters of this opinion(Kattsoff, 1996, p. 176). To them the truth is reality; truth is a meaning which is the case, and because reality is also the case. The true measure of truth depends on methods for acquiring knowledge. Whereas knowledge is only those ideas that are linked appropriately (growing); and the truth is then only the coherence between the ideas or the interconnectedness between propositions (Kattsoff, 1996). 
In this study, the truth is observed with Relativism, precisely Relativism in the moral realm which is defined as: "the view that moral judgments, beliefs about right and wrong, good and bad, not only vary greatly across time and contexts, but that their correctness is dependent on or relative to individual or cultural perspectives and frameworks." (Baghramian \& Carter, 2018) Truth-claim, as the main concern in this paper, is defined as proposition or statement that a particular person or belief system holds to be true (Geanta, 2017). Since the truth is relative, the truth-claim therefore does not hold any absolute truth.

Murray D.L. places truth-claim in the domain of pragmatism. In other words, truth-claim is a hypothesis that is not verified by experience yet.("Define Truth Claim," n.d.) Truth-claim is a judgment therefore, it could not be true absolutely. She wrote:

"Initially, then, every judgment is a truth-claim, and this claim is merely formal. It does not mean that the claim is absolutely true, and that it is impious to question it. On the contrary, it has still to be validated by others, and may work in such a way that its own maker withdraws it, and corrects it by a better. The intellectualist accounts of truth have all failed to make this vital distinction between 'truth-claim' and validated truth. They rest on a confusion of formal with absolute truth, and it is on this account that they cannot distinguish between 'truth' and error. For false judgments also formally claim 'truth,' No judgment alleges that it is false (Murray, 2004, p. 56).

Since truth-claim cannot be called absolute truth, it may be questioned. Even truth-claim will be an error when the evidence that comes after it can refute the truth. Murray further states:

"On the other hand, if the distinction between truth-claims and validated truths is made, there ceases to be any theoretic difficulty about the conception and correction of errors, however difficult it may be to detect them in practice. 'Truths' will be 'claims' which have worked well and maintained themselves; 'errors,' such as have been superseded by better ones. All 'truths' must be tested by something more objective than their own selfassertiveness, and this testing by their working and the consequences to which they lead may go on indefinitely. In other words, however much a 'truth' has been validated, it is always possible to test it further. I.e., it is never theoretically 'absolute,' however well it may practically be assured. For a confirmation of this doctrine Pragmatism appeals to the history of scientific truth, which has shown a continuous correction of 'truths,' which were re-valued as 'errors,' as better statements for them became available."

The truth-claim discussed in this study is actually a subjective and relative form of moral truth. One's belief in a truth claim is one's conclusion after believing in the propositions that are the premise of truth. When the premise changes one's belief in a truth-claim can also shift. While new situations, conditions, challenges facing a person may very well be a new proposition which then becomes the premise to change one's opinion in summing up the truth. Therefore, it is understandable that there are people who shift their belief in the truth. Many then move from a truth to another truth.

In Kuhn's perspective, a shift paradigm occurs when the normal truth faces new challenges (anomalies) so that then new truths are different from the old truths adapted. Kuhn's approach is chosen because the shift paradigm is also conceived on the basis of the assumptions of relativity of truth (Sankey, 2000). Although Kuhn views the all truth as equivalent, Kuhn also 
asserts that the new paradigm is usually viewed not only as distinct, but also better. A paradigm is accepted because of its ability to respond to future promises rather than achievements (Rouse, 2002, p. 150). Reflecting on Thomas Kuhn's theory, shift paradigms are used to see how former terrorists conceptualize three things: old truths, new anomalies, and new truths. With this pattern, the researcher believes that the logic of the former terrorist thought can be completely reconstructed from the beginning of interest in radicalism to terrorism, then proceeds to the factors of truth falsification encountered in various anomalies during terrorism, and finally on the propositions that serve as the premise in recognizing new truths.

Kuhn's theory, however, is not the main framework in this research, but it is an expert that learns much from Kuhn's thoughts, Ian G. Barbour. He is really famous in discussing dichotomy of science and religions. Ian G. Barbour is an American philosopher and professor emeritus of physics and religion at Carleton College in Northfield, Minnesota. He is also outstanding figure in the field of science and religion. lan Barbour is the author of Religion and Science and Ethic in an Age of Technology. Ian Barbour explains the interaction between religion as a truth and science as another truth. lan Barbour's model can be seen as continuum of truthclaim shifting; from conflict to independent, dialog, and integration.

In the phase of conflict, both science is right and religion is wrong or religion is right and science is wrong. They are mutually exclusive and are in conflict that cannot be resolved. The Independence model states that science and religion can be true as long as they are kept in separate and non-overlapping domains. In the model of dialogue, science and religion, partners are in discussion, each bringing their knowledge and uniqueness to enrich the other. However, the real challenge in the dialogue model is the ability to respect each other; both truth claims must respect one another. The integration model brings dialogue and conversation more intensely because the meeting between religion and science is not merely mutual respect and maintaining each other's existence, but has increased to mutual use or cooperation (Justintop, 2010) (Barbour, 1991).

\section{Research Method}

This research is a qualitative research with philosophical approach, particularly philosophy of religion. The study used the approach becuase researchers found many religious concepts that need to be comfirmed by rational explanation. While philosophy of religion is a proper approach to be conducted in that problem. Philosophy is defined as investigation of the nature, causes, or principles of reality, knowledge, or values, which essentially is the logical reasoning rather than empirical grounds.(Company, n.d.) Researchers believe that philosophy is the most appropriate approach to understand the shifting of napiter paradigm. Although researchers prefer to use philosophy an sich, it is also reasonable to put it as Philosophy of Religion since the main focus is religious concepts. Philosophy of religion might be defined as philosophizing about religion (Davies, 1993). Barbour declared that Philosophy of Religion is the use of critical methods of philosophy to clarify the assumption and concepts of various religious traditions (Barbour \& Bailey, 1968).

As a qualitative research, it gathers non-numerical data, both count or measures. It refers to the meanings, concepts definitions, characteristics, metaphors, symbols, and description of 
things" (Berg \& Lune, 2017) Qualitative research is conducted in various academic disciplines but it focuses mainly on the human elements. In less academic contexts, qualitative researches are applied in journalism, business, market research, and non-profits' service demonstrations (Denzin \& Lincoln, 2018, p. 150).

As a philosophical study, the formal object of this research is the idea of truth, while the material objects are ex-terrorism prisoners (ex-napiter) who have either transitioned after involvement in radical-terrorism networks. Thus, this research focused on how former terrorists perceive the truth, begun since they engage in radical networks to abandon radicalism. The three ex-napiter who so far contribute in this research are Yusuf, Mamo, and Wawan.

Data were collected through focus group discussion, interview and library research. In the focus group discussion, researchers engage a small group of participants who consist of three exnapiter and two researchers and two research assistants. The interview conducted semi structured in the sense that the researcher prepared the interview guide but also prepared to accept the development of the discussion outside the questions contained in the interview guide. Researchers also conduct in-depth interviews by speaking with participants in a one-on-one setting. Sometimes the researcher approached the interview with a predetermined list of questions or topics for discussion but allowed the conversation to evolve based on how the participant responded Other times, the researcher has identified certain topics of interest but did not have a formal guide for the conversation, yet allowed the participant to guide it. While the resources study (library research) is used to enrich the data thus strengthening the analysis, especially in finding theories for analytical use. The resources were tracked from various printed sources and online sources. In analyzing the data, this research used inductive way, where researchers collect as much data from informants and related sources and then processed to ultimately drawn conclusions. But in the process, it is certainly considered general philosophical methodologies such as internal coherence, description, comparability, and historical continuity.

\section{Result and Discussion}

The truth-claim shift among ex-napiter can be seen in four processes. Sequentially the process of change will be explained, especially by borrowing lan G. Barbour's framework. The four processes are conflict, independence, dialogue, and integration.

\section{Conflict}

Encounter of two different things is indeed very potential for the occurrence of conflict, including in this case is the encounter of different perspectives or paradigms. Ian Barbour exemplifies how the religious encounter with science which he described as a meeting between biblical literalism and scientific materialism. A literal religion with scientific materialist science is two opposing groups. Ian Barbour also said that religion has deficiencies in terms of experimental evidence as well as publicly justified data while science has objective, open-minded, universal, cumulative, and progressive criteria. The opposition's attitude forms two groups of people, both of which both conduct rhetoric of warfare (Barbour, 2000, p. 11).

The encounter of two different paradigms between radical religion and moderate religion is also very likely to be patterned similar to lan Barbour's analysis. Radical Islam tends to embrace 
literalism while moderate Islam generally claims to be religious in a more scientific, rational and open minded. Because of the sharp differences, both of these views shared rhetoric of warfare. According to Hasyim Muzadi, the basic of conflict paradigm is takfiriyah, pointing other as infidel to claim their own self as true.

Yusuf, ex-napiter who was sentenced to 10 years in prison for being accused of storing explosives, telling of the beginning of his own radical thoughts and being a terrorist. He claimed to have been exposed to radical thinking when he was high school student in Jombang, around 1990s. He joined the Students Islamic Organisation (Rohis). Together with his friends, he claimed to have watched a video about the Bosnian War. The video illustrated how Serbian soldiers massacred Bosnian Muslims, bombed mosques, and thousands of Bosnian Muslims had to flee for safety. After watching the Bosnian video, he felt very angry at the savagery of the Serbian army and empathized with the fate of the Muslims in Bosnia Herzegovina. Yusuf and his friends at that time had thoughts and were called to strive to help Bosnian Muslims in any way such as becoming medical staff (Yusuf, 2018).

Yusuf also recounted that his contact with radical thinking began when he interacted with hardline groups such as Hizbut-Tahrir Indonesia (HTI). At that time, he admired his senior brother (ikhwan) who was an HTI activist and had national achievements. Because of his admiration for his senior, he had been interested in joining HTI. At that time, he also had quite intense interaction and communication with his friends who were activists of the Justice Party. Yusuf said he was interested in consuming Islamic propagandist media such as Sabili magazine, Hidayatullah magazine, and Al-Qolam bulletin. In addition, he also read the translation of Abdullah Azzam's Tarbiyah Jihadiyah book (Yusuf, 2018). The Tarbiyah Jihadiyah book is a collection of writings and lectures delivered by Abdullah Azzam regarding the jihad that he did in Afghanistan against the Soviet Union. This book is widely used as a reference and inspiration for jihadists. Yusuf bought the translation of the Tarbiyah Jihadiyah book from the bookstore of the Ngruki Islamic Boarding School in Surakarta. Besides Tarbiyatul Jihadiyah, Yusuf also reads the translation of the Rasūl alqā'id, bayna al-jurh wa-al-kibriyā 'by Mahmud Muhammad Hamid. Inspired by the contents of the book, Yusuf said that jihad in the sense of fighting infidels is not a deviant thing (Yusuf, 23-82018).

Radical thinking increasingly strengthened when he became a santri kalong (irregular student) in the Al-Islam Islamic Boarding School, Lamongan, East Java. Amrozi and a number of Bali bombing terrorists studied at the Al-Islam Islamic boarding school. Yusuf called this pesantren a small Ngruki boarding school. From this Al-Islamic boarding school he then had the opportunity to "jihad" to Poso, Central Sulawesi. He departed aboard the ship via Pelabuan Surabaya. He sold his motorcycle at a price of 7 (seven) million rupiah. Yusuf lied to his family. He claimed to leave work to wander outside Java and to Malaysia to work.

He traveled to Poso for 7 seven days. While in Poso he deliberately lost contact with his family. In Poso he met with his fellow jihadis from Bima, Aceh, and other regions. Most of them were still young. He was only in Poso for a while because his mentor asked him to go to Malaysia. Not too long in Malaysia, only 15 days. From Malaysia he left for Mindanao, Southern Philippines by sea. He claimed that he was only provided with tickets and pocket money in the form of dollars, ringgit, rupiahs, without documents. All documents were taken by the mentor or guide. 
In Mindanao, Yusuf was forged the knowledge of assembling bombs, demining, and military skill in general. His interaction with the jihadists in Mindanao made him very radical. He claimed that while in Mindanao, he and his friends routinely held recitals, which were to study fiqh jihad which was arranged in the form of classroom learning.

Another former terrorism prisoner, Wawan, also described the beginning of his involvement in terrorism. Wawan claimed to have never been involved in acts of terrorism. He claimed to have been wronged. He was accused of hiding information on criminal acts of terrorism, which was considered to have helped hiding Dr. Azhari and Noordin M. Top. He was arrested as a witness after the arrest of several people who were actually not related. He was considered involved in terrorism only because he had met with terrorists in the same religious forum (pengajian). He felt he was being treated unfairly because he had committed terrorism as alleged to him. During his time as a suspect for seven days he was not accompanied by a lawyer / legal advisor. He also claimed to be intimidated and get physical torture while languishing in bars (Wawan, 23-8-2018).

Even though he never committed acts of terrorism, Wawan still claimed to have a fairly radical Islamic view. Since attending school, Wawan aspired to the establishment of an Indonesian Islamic state. He dreamed of upholding Islamic law in Indonesia. He had radical religious thinking because he often follows pengajian held by hard-line Islamic groups. Both in his hometown, Semarang, and outside the city such as Solo and Sragen. One of them was conscientious in attending the pengajian which was hosted by Ustad Abu Bakar Basyir. In his eyes, Ustad Abu Bakar Basyir had a special charm. The lecture delivered by Ustad Abu Bakar Basyir was able to encourage him in religion (Islam). In addition, Ustad Abu Bakar Basyir was a preacher who always give amazing speech. From the pengajian that he followed, he felt he had a high religious (ghirah) spirit.

If viewed from religious affiliation, Wawan actually is not coming from a radical Islamic group. Wawan claimed to be a member of Muhammadiyah. He even studied at Muhammadiyah Elementary and Middle School. After that he proceeded to the State Mechanical Engineering School. Besides claiming to be a Muhammadiyah memver, he also claimed to have joined PII (Pelajar Islam Indonesia, Indonesian Islamic Students) in 1998. It was in this organization that he learned a lot about leadership. It can be concluded that Wawan views was more caused by factors of interaction and association with the hard-line groups who in this case through the pengajian that he followed.

Meanwhile, Mamo, another ex-napiter, said that he was radicalized by circumstance factor. The circumstance was in term of interactions and relationships with radical people or groups. He recounted the beginning of exposure to radical Islam when he worked at PT Kompas Gramedia, Jakarta, as a contract employee. At that time, he rented a house in the Pacenongan area. In his residence, he often interacted with radical people or groups. Since he frequently prayed in the mosque, he later joined the LDK (Lembaga Dakwah Kampus, Campus Da'wah Institute). In LDK, he got motivation, religious knowledge (Islamiyah diniyah), the development of Islam, jihad, and others. According to his testimony, there was one LDK member affiliated with the Indonesian Islamic State group (NII) 11. After getting acquainted and close to his friend who was an activist for the NII 11, Mamo then followed liqo. It was from this interaction with LDK and 
NII 11 that he claimed to have begun to deal with radical thinking. Moreover, at that time the New Order Government ${ }^{1}$ was very authoritarian where Muslims often get unfair, repressive and discriminatory treatment. At that time, Islamic organizations that were considered radical were not recognized by the state / government and were therefore often called OTB (Organisasi Tanpa Bentuk, formless organizations) (Yusuf, 2018).

Another factor that makes Mamo has radical thoughts and behavior was his interaction with war alumni/Afghanistan jihadists. Mamo interaction and communication with former Afghanistan jihadists was often done through liqo, a small group religious discussion that usually no more than ten people. When the Ambon conflict broke out, Mamo and the Afghan war alumni formed the Kelompok Solidaritas Muslim Ambon (Ambon Muslim Solidarity Team). He felt he was called to jihad in Ambon, which he said was a manifestation of Islamic solidarity. Mamo along with his colleagues from former Afghanistan jihadists were raising funds and buying weapons for jihad in Ambon. In the structure of the Ambon Muslim Solidarity Team, Mamo was appointed to the "Star Team". The task was to select which pilgrims (new member of the group) will be plotted in the da'wah section, which will enter the organizational structure, which ones will be paid for, and which ones will be ordinary member. Everyone who joined he Kelompok Solidaritas Muslim Ambon must have the skills, then it will be determined to which part (Mamo, 2018)

Mamo himself claimed that he had not had time to go to Ambon because there was a Malino agreement. Only in 2008 did he leave for Central Sulawesi, but not Poso. Then he returned to Jakarta to prepare himself for Ambon if at any time Ambon flared up or a conflict ensued. He thought of Muslims in Ambon who were attacked in unprepared conditions. Together with his colleagues, the joint venture fund then brought weapons from Moro, Southern Philippines. In Jakarta, he exchanged knowledge about procedures for unloading weapons. In his view, assembling weapons was not as complicated as he had imagined. In terms of weapons assembly, he claimed to have been trained by Moro War alumni, the Philippines. Mamo was then arrested by Densus 88 on charges of weapons possession (Mamo, 2018).

Yusuf, Wawan, and Mamo consider the ideology that drives their movement as a single truth. While the ideology of the country is considered not in favor of Islam. The idea of most Muslims in Indonesia is considered ordinary thinking with a low Islamic spirit. Therefore, the three ex-napiter felt more noble with the ideology they believed in.

\section{Independent}

In lan Barbour's views, two different paradigms can stand on their own without interfering each other. Each of them can be independent in terms of: questions they ask, the domain to which they refer, and the method applied.(Barbour, 2000) For example, religion focuses on the question of how to form human beings who are moral and well-behaved, while science asks how to form intelligent human beings, inventors and innovators. Regarding domains, religion is more focused on managing private space while science into public space. This is what many campaigns for in liberal society. While related to methods, religion relies heavily on intuition and revelation,

\footnotetext{
${ }^{1}$ New Order era is 32 years political periode in Indonesia since the rise of Soeharto (second Indonesian Presiden) in 1966 to his retire in 1998.
} 
while science on logical and empirical reasoning. By making such distinctions and division of roles, two different paradigms can each be independent and not interfere with each other.

In the context of independent level between Islamic radicals and moderate Islam, it can be mutually independent even though the contrast level is not as sharp as science vs. religion. For example, in the case of anxious questions, radical groups are very serious in asking: how to eradicate the notion of nationalism and then establish the global caliphate of pan Islamism. While the moderate group actually asks how to maintain and strengthen this established country so that it can compete in the global realm. Although both have different perspectives, the focus is still the same that is the relation between religion and state. Second, related to the domain referred to, radical Islam usually targets people from "abangan" backgrounds (the majority of lay people) and targets secular or non-religious people (usually middle and upper groups), while moderate groups tend to work on synergies between organizations that have enormous members like NU and Muhammadiyah. Third, about methods, radical groups prefer the regeneration method and cell network, for example in the form of liqo. While moderate groups tend to use the method of seminarians, research, training, hang-out together, and some fun activities.

Character differences between the radical paradigm of Islam and moderate Islam are certainly a lot, so that both of them seem to be the opposite or separated by thick walls. Often the truth claims they hold encourage each group to accuse the other of being heretical, even infidels.

In addition, according to Barbour, there are alternative ways to separate religion and science, separating the interpretation of the language used by distinguishing its functions.(Barbour, 2000) For example in the context of independent level between radical Islam and moderate Islam, different interpretations of the same language or term can occur. For example, the word jihad for the radicals means almost directly in the direction of qital or war, while the moderate group understood jihad as general seriousness and even avoiding the interpretation of jihad as war. For example, jihad means earnest in learning, working, holding back lust, and so on. Likewise, the word "amaliyah", for radical groups amaliyah means towards the practice of violence such as being a suicide bomber, participating in robbing banks to look for spoils of war and so on. While moderate one interprets amaliyah as positive work, including helping others. Thus, there are very different alterations in meanings for the same term. For lan G. Barbour, this includes the way each group shows its independence.

Yusuf admitted that he began to question his radical thoughts after he was thrown in jail. He began to introspect himself. He felt there was something wrong with what he believed so far. He began to realize that Indonesia was not a conflict country and not a warring country. The condition of Indonesia was not like in the southern Philippines. Therefore, there was no reason to carry out bombings in Indonesia. While in prison he tried to "find" true Islam. He began to interact well with the police and other inmates. That's not enough, as long as it's inside the iron bars, he also tried to make his friends aware. Apart from being self-sufficient, other factors that made him aware that his beliefs and actions were wrong was due to family factor. While in prison, he was disappointed with his radical network. There was no friend from the network that cares about his fate. The only one who cares was his family. He felt sorry for many years lying to his 
family. Even though he had a lot of guilt on his family, his family had forgiven him. His brothers often visited and advised him while he was in prison. One of the concerns, forgiveness and tausyiah of his family made him realize that his thoughts and behavior had been wrong and deviated from Islamic teachings. Another factor that made him aware of radical thinking and terrorism was when he was met by victims of suicide bombings. Although Yusuf did not directly carry out the bombing, he felt terrorism had hurt many innocent people. In fact, many of the victims of terrorism were Muslims themselves. After meeting with the victims, he felt very sorry and even cried.(Yusuf, 2018)

Almost the same as Yusuf, Wawan, another former terrorist prisoner, said that he no longer had radical thoughts after he was thrown into prison. However, he himself felt innocent because he had never been involved in acts of terrorism as had been alleged by the police to him. Although he felt he was wronged and got unfair treatment, he did not antipathy to the government and tried to return to the community better. The prison made him realize that radicalism, especially terrorism, cannot be justified in Islam. After getting out of prison he felt better. He did not want to take part in the recitation held by hardline Islamic groups. Another factor that made him no longer radical was his encounter with Yusuf.

Similar to Yusuf and Wawan, Mamo also claimed to question the paradigm of his radical diversity thinking after he was put in prison. While in prison with other terrorism prisoners, he began to think about how he would be more useful for Muslims, how to interpret jihad, and how to interpret Indonesia's current condition. Musahabah led him to the realization that all this time his thoughts were wrong. He realized that Indonesia was not a war country. Indonesia is not darul harb. He then disagrees with ISIS's view that Indonesia is darul harb, where jihadiyah practice can be done in Indonesia. Therefore, acts of terrorism and against the government are actions that cannot be justified by anyone, including Islam. Moreover, many victims of terrorism have also come from Muslim (Mamo, 2018).

\section{Dialogue}

The third stage in the process of transitioning truth claims is dialogue between the old paradigm and the new paradigm. Dialogue in this context is interpreted as a further effort to answer doubts that began to emerge at an independent stage. The dialogue level is the peak stage of the two paradigm conflicts, before finally being able to accept new truths at the level of integration. Dialogue is also a stage of evaluation of two truth claims that are being met.

Theoretically, Ian G. Barbour acknowledges that the religious paradigm as an old paradigm is more resistant to falsification, but at the same time not immune to new challenges.(Barbour, 2000) At the same time the new paradigm has a limit-question so it is unable to provide a complete answer. Barbour described "the limits of the questions arising from science but not answered within science itself" (Barbour, 2000: 24). This means that a new, more scientific paradigm is not necessarily able to provide answers to all problems. These two conditions indicate that both the old paradigm and the new paradigm still have weaknesses, so they need to be met.

Even though the old paradigm is resistant to all forms of falsification, but actually the old paradigm also cannot reject the challenge of renewal. In the previous chapter, it was explained 
how the napiter resists to the old paradigm of reform, where the approach they used initially was conflict, even hostile to the new paradigm. Then when realizing that the new paradigm has a power that cannot be ignored, the napiter makes segregation or limitation so that they appear independent. But at this stage of the dialogue, the gap that was built has begun to be opened. This indicates that the barrier between the old paradigm and the new paradigm begin to collapse. Napiters begin to find out what are the advantages of the new paradigm. In other words, napiters who were previously closed-minded turned into more open-minded and willing to listen to other opinions, even actively finding out and testing these new opinions.

For example, Yusuf listened and received input from $\mathrm{NHI}$, a moderate scholar who is expert on radicalism. Feedback from NHI was certainly an intake that leads to moderation. $\mathrm{NHI}$ is a pesantren alumni who has worked for the Washington Post and continued his education in doctoral programs in Australia, so that besides being strong in Islam he is also rich in experience with modernity, and has high intellectual ability. Yusuf acknowledged that the NHI method did seem relaxing and not patronizing, even tends to be friends. The moderate ideas of the NHI were only conveyed casually, in a relaxed manner, far from the impression of imposing an opinion. The usual discussion began with talk about the business being carried out and then touched on issues of moderate social awareness, national awareness and Islam. NHI himself has the principle of starting from the heart before getting to the head. Touched his heart first, no need to rush to change his ideology. In this way, Yusuf felt more 'someone' as a friend, not just as an object of the project as Yusuf has complained about BNPT treatment.

The same process can be seen in the context of Yusuf relationship with several napiter. Yusuf has turned into a moderate person who has a lot of dialogue with napiter who is still in detention and ex-napiter who has been released. In radical networks, Yusuf is considered a "government agent" or "BNPT person" that is used for deradicalization. This is because Yusuf has repeatedly shown his partiality to moderate ideas when appearing in public in seminars, conferences, discussions, and television talk shows. But as a fairly senior person in radical networks, Yusuf has a good mastery of Islam and understands the radical anatomy of matter.

Yusuf's ability to understand radical networks and expertise to package the idea of moderate Islam makes him to be able to translate the invitation to moderate Islam with language and radical network-style communication techniques. This is very beneficial, because not everyone is able to speak in a way that is typical of radical networks. The choice of words, greetings, gestures, expressions, jokes that are typical of "ikhwan" (it means brother, calls by fellow radical network members) cannot always be practiced by ordinary people. Therefore, the presence of Yusuf who appears like ikhwan in general, but whose head contains moderate ideas, is a unique opportunity to influence napiter and ex-napiter.

Wawan acknowledged that his choice to take a moderate path was the result of his dialogue since when he was in prison. One of the culminating moments of the dialogue Wawan reached was when he got word of parole. That moment that he made as a milestone in change because at that time he made a pledge through prayer:

"God, if indeed my PB management cannot be smooth (it will not be released) then this is the best for me and in the future, I will be better for all Muslims (later more radicals), but if PB is smooth then I will do best for my family (no more radical)." (Wawan, 2018) 
Finally, the PB (Pembebasan Bersyarat, Free Decision Letter) was successful and Wawan was declared parole. The free statement for Wawan was quite miraculous, because the letter was hidden between the common criminal inmates who tripped over drug cases, so that the letter was not detected by Densus 88 . According to Wawan, Densus 88 often checks and makes it difficult for napiter to be released.

In addition to these experiences, the meeting between Wawan and Yusuf was an important factor because Yusuf helped Wawan to be consistent in the moderate way. Yusuf invites to useful social activities so that he will not easily be persuaded to return to the radical path. Wawan was once invited back to radical group by an old friend who had joined ISIS, but Wawan firmly refused. Wawan said: "If the business is good, I don't need to be picked up, surely I will arrive earlier than you - I can't possibly enter the lizard's hole second time." Thus, Wawan has seen radical activities as "not good". It means that there has been a very sharp shift shortly after Wawan was declared free.

For the case of Mamo, dialogue about truth took place in prison, especially after seeing a lot of differences among the jihadists themselves, there was even a gap between NII-style groups and those who supported ISIS. These differences between fellow jihad fighters made Mamo doubt the radical path he had been through. While on the other hand, the encounter with religious counselors while in prison, then social assignments given, for example teaching iqro (a book to master Arabic letter) to adolescent drug addicts while in prison, also touch the human side of Mamo to change the path of struggle to be more positive, and leave the radical path.

Unlike Yusuf, the dialogue he felt was about loyalty. When in prison Yusuf felt that he was not visited by any of his comrades in jihad, felt abandoned and ignored by the network. While his family had always been giving attention and encouragement. This eliminated the loyalty to radical networks and strengthens the mental of returning to normal life. The total change of Yusuf's partiality on the moderate path occurred when he was increasingly invited to seminars and met other moderate speakers, including his friendship with NHI.

In the dialogue stage, according to lan G Barbour, limit-situations can occur which are expressions of recognition of the existence of religious dimensions in science, in other words recognition of the existence of part A paradigm that is included in the B paradigm, or vice versa.(Barbour, 2000) If this model of thinking is borrowed to analyze the relation of the old paradigm and the new paradigm among napiter, it will be understood that the new paradigm is actually also supported by several dimensions of the old paradigm. In addition, a new paradigm that has certain truths also still has weaknesses that make it not a single and final choice. This awareness aside from acknowledging the interrelationship of two different paradigms, it also functions as a brake so that one is not rushed to enter totally in the new paradigm. This awareness is also the seeds of integration that will be achieved in the fourth stage later. Then it is important to reveal the dialogue between the old paradigm and the new paradigm in this section.

Science and religion can dialogue because they have parallel elements, or the same characteristics; lan G. Barbour calls it parallel methodological and conceptual parallel. What is meant by parallel methodology is the use of consistency and congruence with experience. The method is equally used by science and religion. The old paradigm and the new paradigm also 
have parallel methodologies in the sense of using experience to determine truth. In the context of napiter's experience, they had dialogue about the experiences gained both while still in a radical network and after meeting new experiences and moderate ideas. The two types of experiences were met and confronted.

Whereas, the conceptual parallel emphasizes the recognition of the similarity of concepts between religion and science. For example, the concept of God Creator is considered to be similar to the concept of an independent process of information communication.(Barbour, 2000) The old paradigm also has similarities of concepts with new paradigms. For example, the old paradigm of wanting Islam to become rahmatan lil amin alamin (bless for universe), as well as a new paradigm. The concept of rahmatan lil'alamin in these two paradigms is equally concerned with the protection of non-Muslims. The only difference lies in the practice. In the old paradigm the protection of non-Muslims was given under Shari'a law regulated by Muslims based on the Qur'an and Hadith. Shari'a institutions are the umbrella for the implementation of protection against non-Muslims. But in the new paradigm, the practice does not require the formalization of the Shari'a, but with state law it can be used to provide protection to non-Muslims. State law is compiled with a democratic mechanism whereby most members who convene are also Muslim and heed religious teachings. The end of this dialogue process is the creation of an integrative new paradigm and the loss of determinative criteria. Thomas Kuhn explained that with the initiation of a new paradigm the old data would be reinterpreted and would be seen in a new way and finally a new kind of data would be created.(Kuhn, 1970) When choosing between the two paradigms, there are no more determinative rules or criteria (Barbour, 2000).

\section{Integration}

In this integration phase lan G. Barbour mentioned a model of integration that took place among bearers of natural theology where integration proceeded from the lives of religious groups who questioned how their beliefs needed to be reformed according to the development of modern science.(Barbour, 2000) For the context of this study, the old paradigm or previous truth-claim that was radically patterned was reconstructed according to the awareness gained during the process of dialogue with the moderate paradigm. With this integration, napiter becomes more moderate and cooperative even though the spirit of Islam is still very visible and still resembles old habits, especially at the ritualistic level. If you observe these three napiter, they still physically look like ikhwan in general, for example cingkrang pants (pants that tip above the ankles). Then also in the aspect of religious ritual they are still the same. The difference lies in the way of thinking and looking at the truth.

According to Barbour, systematic integration takes place in integration that enables one to build an inclusive paradigm. While for the synthesis to occur, a process of deep thinking (philosophical) is needed by considering two different paradigms. Ian G Barbour said: "in a systematic synthesis and science of religion and contribute to the development of inclusive metaphysics, such as that of process philosophy" (Barbour, 2000). Thus, an inclusive paradigm is the result of the process of thinking deep by considering the values that exist in radical ideology and values in moderate thinking. 
After turning into moderation, there appears to be some shift in views among ex-napiter. The first is related to thaghut and ansharut thaghut. In general, radical networks regard the state as thaghut, while state apparatus includes the police, and even civil servants, as part of ansharut thaghut (maid of evil). Now Yusuf, Mamo, and Wawan have moderate views on thaghut. According to Yusuf, thaghut means the party who wants to be worshiped and he is willing to worship it. Indonesia as a nation is not tagged because there are no rulers worshiped such as fir'aun, Indonesia is actually built through Muslim ijtihadiyah (effort of thinking). If the former scholars agreed to establish this nation as a form of mutual agreement, it must be accepted as a result of the ulama's ijtihad. Therefore, the state is not thaghut.

The concept of ansharut thaghut which is identified by the radicals with the police (especially Densus 88) is an understanding that the apparatus is a tool used by thaghut to oppress Muslims. Furthermore, the attitude of the radicals towards the police was increasingly not on target when the traffic police tasked in maintaining the the stability of traffic were also targeted by terror. This is because radical groups shift their targets to groups that they can reach. So that, there are terms far target and near target. If they cannot be able to target the head of thaghut (president), the next target is the assistants. If you can't target Detachment then traffic police are allowed too. For the three ex-napiters, the concept above was wrong and deliberately carried out to provoke war or change Indonesia as a peaceful country (darus salam) to darul harb (territory of war). If they succeed in transforming Indonesia into darul harb, then various bad possibilities will be easily to happen. Mamo said:

If an area has been considered darul harb, then the conflict is very easy. Whatever is done becomes permissible because it has become a territory of war. For example, ISIS considers Indonesia darul harb, so it can do amaliyah, jihadiyah activities. The Syrian concept would be brought to Indonesia (Yusuf, 2018).

Yusuf also did not agree that Indonesia is considered darul harb. The war in Yusuf's view was the military against the military as happened in the history of the apostle. Indonesia is not a country that is at war, different from Palestine, then Indonesia is not darul harb. Yusuf said:

"About Darul Harb, I agreed that the military would meet the military. As it was the case in the prophet era. Afghans are civilians. Palestine there is a war, that's darul harb. But Indonesia has no war, Indonesia is not darul harb" (Yusuf, 2018).

The ex-napiter also no longer agrees with the Islamic caliphate struggle and the Islamic state (daulah). They prefer to apply Islamic values in society peacefully rather than impose a khilafah (Caliphate system). However, in the current climate of regional autonomy, in the majority of Muslim regions, they want regulations that are in accordance with sharia so that Muslims can be more stable in worship. According to Yusuf:

"I used to think daulah was the path to khilafah. Freeing up the territory of Indonesia, Malaysia, the Philippines, then awakening the Caliphate. Now I see that ideally this most autonomy is added to the sharia regulations if there are Muslims there and the ideal number, it is more pervasive, it makes more sense than daulah and khilafah (Yusuf, 2018). Thus, in this stage of integration there have been significant changes in the realm of truth claims. Although certain aspects of Islam that they gained from the old paradigm were still carried 
on, especially in terms of ritualistic obedience, their perspective on differences became much more open, so they were able to be moderate.

\section{Conclusion}

Based on the data and analysis in this study, it can be concluded to several points:

1. The shift in truth claims among the ex-Napiter occurs gradually. Each stage involves dialectic of strong thinking, or in the term of lan G. Barbour called Process Philosophy.

2. The concept of the old truth that is believed by Napiter is held firm in the stage of conflict. The stage of conflict occurs when radical circles still operate in their networks. The truth that they profess is in sharp contrast to the values of truth that are believed by moderates. Radical groups tend to be literal, while moderate groups are more rational. In this stage Napiter still believes in the old truth which includes: the necessity of the establishment of the Caliphate or at least the Islamic State because of the principle that there is no law except Allah's law, the obligation of jihad to fight for the religion of Allah and defend the fate of Muslims, and the belief in the existence of the enemy power.

3. Factors that drive truth-claim shift start occur at an independent stage. The independent stage is experienced by those who are caught and become prisoners of terrorism cases (napiter). The initial dialectic that they feel is the recognition of the existence of two possibilities, each of which has truth and goodness. The first possibility is a radical ideology which he believes, while the second is moderate ideologies carried by other parties and supported by the state.

4. The process of change takes place in three various factors that have led to intensive dialogue within a napiter. The dialogue stage happens when napiter sees two things: weakness in one's own network and strength or goodness in the state's ideology. Weaknesses in the network itself, for example, can be seen from disputes and gaps arising among fellow jihadists during their detention period. For example, the NII group disputed with ISIS, even though they were both Islamic jihadists. Another factor that shows the weakness of radical ideology is the absence of solidarity. Napiter feels discarded by his fellow jihadis because they had never been visited, and the family left behind at home was not maintained by the network so that life was miserable. On the other hand, napiter sees the potential for good from the state and moderate ideological bearers. For example, when they are trusted to teach iqro to prisoners of drug cases, also the attention of government's religious advisers in prisons who often share happiness with napiter. This attitude is in contrast to the negligent attitude shown by their old network.

5. A new view of truth is formed when napiter enters the stage of integration. The stage of integration is achieved when napiter has gone beyond systematic synthesis, namely when they have been thinking deeply for a long time by considering what they experience while still radical, experience in prison time, and meeting people with moderate ideology. At this stage of integration, they have had a moderate view including when asked about important concepts in radical ideologies such as jihad, darul harb, thaghut, ansharut thaghut, daulah Islam, and khilafah. Their views have been very inclusive and moderate, and no longer agree with ways of coercion and violence. 
The finding of the research is important to understand the changes of mind among ex-napiter and the factors that cause these changes. The government, particularly ministry of education, can formulate policies, for example by rearranging the curriculum, which can reduce the spread of radical Islamic thought in Indonesia.

\section{Acknowledgement}

This research was carried out with the support of Muhammadiyah University of Surakarta through the 2018 Doctoral Research Grant. We thank colleagues who have played a role in this research, both in providing their information, perspectives, and expertise even though this research might not be able to achieve what they expected. We also thank to Lembaga Pengembangan Publikasi IImiah, Scientific Publication Development Institute (LPPI) and to the mentors on the Writing and Publishing of Scientific Journal Papers at Universiti Tun Husein Onn Malaysia, for their assistance with monitoring, evaluation, and discussion that greatly improved the manuscript.

\section{Corresponding Author}

Aminuddin Hassan is associate professor at the Faculty of Educational Studies, Universiti Putra Malaysia, 43400 UPM Serdang, Selangor Darul Ehsan, Malaysia.

Email: aminuddin@upm.edu.my

\section{References}

Baghramian, M., \& Carter, J. A. (2018). Relativism. In E. N. Zalta (Ed.), The Stanford Encyclopedia of Philosophy (Winter 201). Metaphysics Research Lab, Stanford University.

Barbour, I. G. (1991). Religion in an Age of Science. Aberdeen: HarperCollins.

Barbour, I. G. (2000). When Science Meets Religion: Enemies, Strangers, or Partners. New York: Harper Collins.

Barbour, I. G., \& Bailey, J. M. (1968). Issues in Science and Religion. American Journal of Physics, 36(6), 562-563. https://doi.org/10.1119/1.1974993

Berg, B. L., \& Lune, H. (2017). Qualitative research methods for the social sciences (Ninth edit). Boston: Pearson.

Company, H. M. H. P. (n.d.). The American Heritage Dictionary entry: philosophy.

Davies, B. (1993). Introduction to the Philosophy of Religion (2nd ed.). Retrieved from https://monoskop.org/images/b/bf/Davies_Brian_An_Introduction_to_the_Philosophy_of _Religion_2nd_edition_1993.pdf

Define Truth Claim. (n.d.). In Dictionary.com. Retrieved from https://www.dictionary.com/browse/truth-claim

Denzin, N. K., \& Lincoln, Y. S. (eds. . (2018). The SAGE Handbook of Qualitative Research. Los Angeles: SAGE.

Fathurahman. (n.d.). Teroris Tobat Ini Sering Diteror dan Disebut Pengkhianat. Retrieved from https://www.tribunnews.com/regional/2015/11/28/teroris-tobat-ini-sering-diteror-dandisebut-pengkhianat

Geanta, A. (2017). Truth Claims - Free Will - Determinism. Retrieved November 20, 2018, from 
INTERNATIONAL JOURNAL OF ACADEMIC RESEARCH IN BUSINESS AND SOCIAL SCIENCES Vol. 9, No. 10, October, 2019, E-ISSN: 2222-6990 @ 2019 HRMARS

https://philosophy.stackexchange.com/questions/47077/truth-claims-free-willdeterminism

Justintop. (2010). Science and Religion: Barbour's 4 models - A biologist's view of science \& theology. Retrieved from

https://scienceandtheology.wordpress.com/2010/11/11/science-and-religion-barbours-4models/

Kamal, M. (2008). The Meaning of Terrorism: A Philosophical Inquiry. 1(1), 1-11.

Kattsoff, L. O. (1996). Pengantar Filsafat, terj. Soejono Soemargono. Yogyakarta: Tiara Wacana.

Kesimpulan. (2009, July). Disertasi Mantan Kepala Badan Intelijen Negara (BIN) AM Hendropriyono Judul Terorisme dalam Kajian Filsafat Analitika Predikat Cum Laude.

Retrieved from CONCLUSION website: https://kesimpulan.com/en/page/753/

KompasTV. Mantan Teroris Dirikan Pesantren untuk Deradikalisasi - YouTube.

Kuhn, T. S. (1970). The structure of scientific revolutions ([2d ed., e). Chicago: University of Chicago Press.

Movanita, A. N. K. (n.d.). Interaksi dengan Korban Bom Bali Membuat Iqbal Husaini Kapok Jadi Teroris - Halaman 3 - Tribunnews.com. Retrieved October 11, 2018, from https://www.tribunnews.com/nasional/2017/06/09/interaksi-dengan-korban-bom-balimembuat-iqbal-husaini-kapok-jadi-teroris?page $=3$

Mufid, F. (2016). Radikalisme Islam Dalam Perspektif Epistemologi. ADDIN, 10(1), 61. https://doi.org/10.21043/addin.v10i1.1129

Murray, D. L. (2004). Pragmatism. Project Guttenberg.

Nursalim, M. (2014). Deradikalisasi Terorisme: Studi Atas Epistemologi, Model Interpretasi dan Manipulasi Pelaku Teror. Kalam: Jurnal Studi Agama dan Pemikiran Islam, 8(2), 329-346.

Rouse, J. (2002). Kuhn's Philosophy of Scientific Practice. In T. Nickles (Ed.), Thomas Kuhn (pp. 101-121). Cambridge: Cambridge University Press.

Sankey, H. (2000). Kuhns Ontological Relativism. Science and Education, 9(1-2), 59-75.

Viva Media Baru, P. (2017, July). Berapa Jumlah Napi Teroris di Indonesia.

Yusuf. (2018, August). Interview.

Abruscato, J. \& DeRossa, D. A. (2010). Teaching Children Science: A Discovery Approach 7th edition, Allyn \& Bacon : Boston

Yun, C. J. (2012). Effects of using Hands-on Teaching in Science Teaching and Learning Proces. Research Seminar, 2012, (165-179)

Exley, K. \& Dennick, R. (2004). Giving a lecture: From presenting to teaching. London: Routledge Falmer.

Hacker, D. J., Dunlosky, J., \& Graesser, A. C. (Eds.). (1998). The educational psychology series. Metacognition in educational theory and practice. Mahwah, NJ, US: Lawrence Erlbaum Associates Publishers.

Malaysia Ministry of Education. (2013). Malaysian Education BluePrint (2013-2015). Ministry of Education: Kuala Lumpur.

Malaysia Ministry of Education. (2014). Higher Order Thinking Skilss. Ministry of Education: Kuala Lumpur. 
INTERNATIONAL JOURNAL OF ACADEMIC RESEARCH IN BUSINESS AND SOCIAL SCIENCES

Vol. 9, No. 10, October, 2019, E-ISSN: 2222-6990 @ 2019 HRMARS

Malaysia Ministry of Education. (2014). Third International Research on Science and Mathematics. Ministry of Education: Kuala Lumpur.

Ibrahim, M. A., \& Husain, R. (2014). Mastery of Observation Skill and Predicting Skill in Science among Standard Five students in Johor Bharu District. Education Journal Faculty Of Education University Teknologi Malaysia, 15(3), 35-42.

Ghafar, N., Ibrahim, A. R. (2011). Evaluation of Relationship Between Level of Science

Concept and Level of Science Process Skills of Teacher. Journal Of Science And

Mathematics Educational, Volume 3 Sept 2011, 1-19

Nessel, D. D., \& Graham, J. M. (2007). Thinking Strategies for student achievement: improving learning a cross the curriculum, $K-12$. ( $\left.2^{\text {nd }} e d.\right)$. Thousand oaks, Carlifonia: Corwin Press. A SAGE Publication Company.

Pallant, J. (2013). SPSS survival manual: A stepby step guide to data analysis using SPSS (5th ed.). England: McGraw Hill.

Revell, A. \& Wainwright, E. (2009). What makes lectures "unmissable"? Insights into teaching excellence and active learning. Journal of Geography in Higher Education,

Lee, S. T. (2009). Examining the Relationships between Metacognition, Selfregulation and Critical Thinking in Online Socratic Seminars for HighSchool Social Studies Students. University of Texas at Austin, 07,1042.doi01.12331/j.1237-8991.2011.0674.

Synder, L. G., \& Synder, M. J. (2008). Teaching critical thinking and problem solving skills. The Delta Phi Epsilon Journal, L (2), 90-99.

Sulaiman, T., \& Rahim, N. A. A. (2010). Various effective approaches in science teaching. Universiti Putra Malaysia: Publication of University Putra Malaysia.

Budiman, Z. B. (2008). Development of Cognitive Conflict Module and its effect on Cognitive Development and Science Achievement. Doctoral dissertation. National University of Malaysia, Bangi, Selangor. 